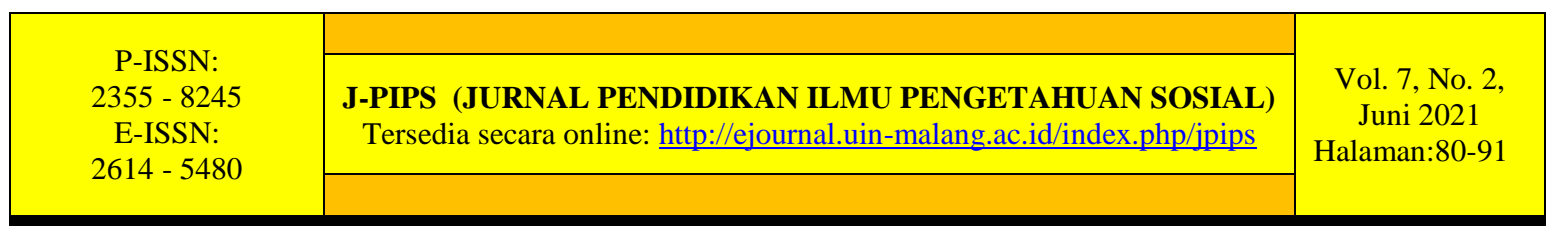

\title{
Kesiapan Belajar Jarak Jauh Siswa SMP di Kota Malang
}

\author{
Ganesha Sekar $^{1}$, Agus Purnomo ${ }^{2 *}$, Agung Wiradimadja ${ }^{3}$ \\ 1,2,3 Universitas Negeri Malang, Jl. Semarang No.5, Malang, Jawa Timur, Indonesia \\ ganeshasekarayu@ gmail.com ${ }^{1}$, agus.purnomo.fis@um.ac.id ${ }^{2}$, \\ agung.wiradimadja.fis@um.ac.id ${ }^{3}$
}

Diterima: 15-02-2021.; Direvisi: 06-12-2021; Disetujui: 17-06-2021

Permalink/DOI: $10.15548 /$ jpips.v7i2.11669

Abstrak: Pandemi Covid-19 berdampak pada semua aspek, termasuk dunia pendidikan. Pandemi ini juga berdampak pada pendidikan di Kota Malang, Dinas Pendidikan menerapkan kebijakan belajar dari rumah. Penerapan selama dua semester menunjukkan bahwa baik pihak sekolah dan siswa relatif belum siap sepenuhnya untuk terlibat dalam kegiatan pembelajaran jarak jauh. Atas dasar tersebut, artikel ini bertujuan untuk mengetahui kecenderungan kesiapan belajar terhadap pemahaman materi siswa SMP di Kota Malang selama mengikuti pembelajaran jarak jauh. Pendekatan kuantitatif desain survey cross sectional dipilih guna menjawab tujuan artikel ini. Data kesiapan belajar siswa dikumpulkan dari seluruh SMP Negeri di Kota Malang sebanyak 400 orang yang ditentukan dengan perhitungan Slovin dengan derajat kesalahan 5\%. Teknik pengumpulan data menggunakan kuesioner online (Google Form). Data yang dikumpulkan dikelola melalui tahap editing, scoring, coding, dan tabulating yang menjadi dasar untuk melakukan analisis tabulasi silang. Hasil temuan lapangan menunjukkan bahwa siswa SMP Negeri di Kota Malang yang memiliki tingkat kesiapan belajar yang tinggi dan cenderung memiliki pemahaman materi dengan persentase ratarata $60 \%$. Implikasi hasil temuan ini memberikan kontribusi dalam memahami pelaksanaan pembelajaran jarak jauh dari sudut pandang siswa terkait aspek kesiapan. Rekomendasi untuk penelitian selanjutnya berkaitan dengan bagaimana pengelolaan pembelajaran jarak jauh dilakukan berdasarkan profil kesiapan yang ada.

\section{Kata Kunci: Kesiapan Belajar; Pembelajaran Jarak Jauh; Pemahaman Materi}

\section{Distance Learning Readiness of Junior High School Students in Malang City}

Abstract: The Covid-19 pandemic has an impact on all aspects, including education.
This pandemic also impacts education in Malang City, and the Education Office has
implemented learning from home policy. However, implementation for two semesters
shows that both the school and students are relatively not ready to be involved in
distance learning activities. This article aims to look at the tendency of learning
readiness to understand the material of Junior High School students in Malang City
during distance learning. The quantitative survey approach answers questions that
answer the purpose of this article. The calculation of Slovin determined student
readiness data collected from all state Junior High Schools in Malang City as many as 
400 people with a degree of error of 5\%. The data technique uses an online questionnaire (google form). The data is managed through the editing, scoring, coding, and tabulating stages, which are the basis for conducting a cross-tabulation analysis. Field findings show that public Junior High School students in Malang City have a high level of learning readiness and tend to understand the material with an average percentage of $60 \%$. The implications of these findings contribute to understanding the implementation of distance learning from the student's point of view regarding the aspect of readiness-recommendations for further research related to how distance learning is managed based on the existing readiness profile.

\section{Keywords: Readiness to Learn; Distance Learning; Retention of Material}

\section{PENDAHULUAN}

Pembelajaran jarak jauh pada masa darurat Covid-19 pada akhir tahun ajaran 2019/2020 memberikan dampak yang signifikan dalam sistem pembelajaran di Kota Malang. Selama pandemi Covid-19, pemerintah menyepakati kebijakan baru tentang pendidikan yaitu pendidikan untuk sementara diganti dengan sistem pembelajaran online atau daring (dalam jaringan) untuk tingkat sekolah maupun perguruan tinggi (Kemendikbud, 2020). Menteri Pendidikan dan Kebudayaan, Nadiem Anwar Makarim menerbitkan Surat Edaran Nomor 3 Tahun 2020 pada Satuan Pendidikan dan Nomor 36962/MPK.A/HK/2020 tentang Pelaksanaan Pendidikan dalam Masa Darurat Coronavirus Disease (Covid-19) maka kegiatan belajar dilakukan secara daring dalam rangka pencegahan penyebaran Covid-19. Sistem pembelajaran daring memanfaatkan sistem teknologi digital seperti Google Classroom, Zoom, Google Meet, laptop, dan masih banyak lagi (Kemendikbud, 2020).

Sistem pembelajaran daring pada tingkat sekolah khususnya menengah, sistem pembelajaran seluruhnya dilakukan dengan sistem Pembelajaran Jarak Jauh (PJJ) yang dilakukan melalui Google Classroom, Google Meet, Zoom, dan WhatsApp Group dalam penyampaian materi pembelajaran, proses pembelajaran hingga evaluasi pembelajaran. Pembelajaran jarak jauh merupakan pembelajaran yang dialihkan dengan metode jarak jauh baik dalam jaringan atau tidak (Tilak \& Glassman, 2020). Pada dasarnya pada pembelajaran jarak jauh adalah upaya untuk memelihara dan mengelola interaksi dalam pembelajaran. Pembelajaran terdapat interaksi antar siswa, siswa dengan materi, dan siswa dengan pendidik, namun dalam pembelajaran jarak jauh terdapat komponen tambahan yaitu sistem. Sistem ini yang membantu kita menghubungkan siswa dengan pendidik melalui Learning Management System (LMS) (Garrison \& Archer, 2010). Pembelajaran jarak jauh, ada bagian yang terkadang memanfaatkan perangkat elektronik dalam penyampaian/interaksi pendidik dan peserta didik melalui kaset atau video, kondisi ini memunculkan istilah e-learning. Pembelajaran jarak jauh merupakan proses pendidikan yang terorganisasi yang menjembatani jarak antara siswa dengan pendidik dan dimediasi oleh pemanfaatan teknologi, dan pertemuan tatap muka yang minimal (Ristekdikti, 2016)

Kota Malang merupakan salah satu wilayah yang melaksanakan penerapan pembelajaran jarak jauh, tetapi kebijakan yang diterapkan pemerintah Kota Malang dalam perubahan sistem pembelajaran tidak selalu diterima begitu saja oleh sebagian instansi, guru maupun siswa. Perubahan sistem pembelajaran memerlukan adaptasi bagi guru dan siswa untuk menyesuaikan kondisi dan kemampuan dalam mengikuti proses pembelajaran jarak jauh. Hal ini mengakibatkan banyak sekolah yang tidak siap dengan 
perubahan sistem pembelajaran jarak jauh melihat kondisi masing-masing guru dan siswa (Sutiaji, 2020). Salah satu aspek yang berpengaruh dalam kelancaran pelaksanaan pembelajaran jarak jauh adalah kesiapan siswa. Pembelajaran jarak jauh dianggap sebagai satu-satunya kebijakan yang memungkinkan proses pembelajaran tetap bisa dilakukan di tengah pandemi Covid-19. Penerapan pembelajaran jarak jauh terdapat dua masalah utama yang menghambat efektivitas proses pembelajaran yaitu keterbatasan akses terhadap internet, keterbatasan kapabilitas tenaga pengajar dan kesiapan siswa dalam menerima pembelajaran jarak jauh (Santosa, 2020). Pemerintah pusat pun tidak memberikan arahan yang spesifik dan detail dalam pelaksanaan pembelajaran jarak jauh di masa pandemi Covid-19 sehingga guru dan sekolah dituntut untuk berinovasi dan membuat kebijakannya masing-masing.

Analisis kesiapan siswa sebagai menjadi kebutuhan untuk mendesain pembelajaran jarak jauh yang efektif. Keadaan ini memaksa pembelajaran harus dilakukan dengan melakukan interaksi secara digital untuk menyapa siswa dan memberikan materi dan tugas yang harus siswa lakukan di rumah. Namun tidak serta merta pembelajaran daring dapat langsung digunakan dalam suatu lingkungan sekolah, berhasil tidaknya pencapaian tujuan pendidikan banyak bergantung kepada proses belajar yang dialami oleh siswa (Kristanto, 2020).

Proses belajar yang berpengaruh bagi tujuan pendidikan yang berlangsung salah satu faktor psikologi yang ada di dalamnya adalah kesiapan (Slameto, 2013). Kesiapan adalah keseluruhan kondisi seseorang yang membuatnya siap untuk memberi respons atau jawaban di dalam cara tertentu terhadap suatu situasi (Slameto, 2013) . Kesiapan untuk memberi tanggapan itu timbul dari dalam diri seseorang dan juga berhubungan dengan kematangan, karena kematangan berarti kesiapan untuk melaksanakan kecakapan. Kesiapan ini perlu diperhatikan dalam proses belajar, karena jika siswa belajar dan sudah ada kesiapan, maka hasil belajarnya akan lebih baik (Slameto, 2013). Kesiapan belajar siswa dapat digambarkan dari kondisi internal dan eksternal siswa. Kondisi internal merupakan kesiapan yang dilihat dari faktor psikis.

Data kesiapan belajar siswa dari hasil survei menunjukkan bahwa 67\% siswa belum siap dengan pola belajar yang baru (Purnomo, 2020). Secara umum, pada pembelajaran jarak jauh siswa masih ada kendala teknis pembelajaran daring dikarenakan sebagian besar baru pertama kali melaksanakan pembelajaran penuh dengan sistem online learning pada situasi pandemi Covid-19 ini. Kondisi ini menyebabkan mereka belum terbiasa terkait dengan tata cara atau sistem pembelajaran online learning. Dibutuhkan kemampuan adaptasi yang baik dari mereka untuk dapat siap menjalani pembelajaran (Setiaji \& Dinata, 2020). Mereka memiliki beberapa kendala seperti, tidak mampu mengakses sumber belajar atau kondisi lingkungan belajar yang kurang mendukung. Bahkan di daerah Nusa Tenggara karena orang tua mengajak siswa untuk bekerja di pagi hari, dinas pendidikan bekerja sama dengan Radio Republik Indonesia (RRI) untuk melakukan siaran pembelajaran (Sabuga, 2020). Oleh karena itu studi tentang kesiapan belajar jarak jauh siswa di Kota Malang menjadi hal yang penting dilakukan dalam memberikan rekomendasi pengelolaan pembelajaran jarak jauh yang lebih efektif.

\section{METODE}

Pendekatan kuantitatif dengan desain cross sectional survey yang menjaring data dari siswa di SMP Negeri di Kota Malang pada saat siswa melaksanakan pembelajaran jarak jauh karena dalam masa pandemi Covid-19 pada bulan September-Januari 2020. 
Populasinya mencakup siswa SMP Negeri di Kota Malang yang berjumlah 19787 siswa (Tabel 1).

Tabel 1. Populasi Siswa SMP Negeri di Kota Malang tahun 2019/2020

\begin{tabular}{lc}
\hline Kecamatan & Jumlah Siswa (orang) \\
\hline Kedungkandang & 4279 \\
Sukun & 2491 \\
Klojen & 5671 \\
Lowokwaru & 4289 \\
Blimbing & 3057 \\
\hline Total & 19787 \\
\hline
\end{tabular}

Sumber: BPS.go.id (2020)

Penentuan sampel menggunakan perhitungan slovin dengan teknik simple random sampling (Formula 1). Dari hasil perhitungan tersebut diketahui bahwa jumlah sampel responden dibulatkan sejumlah 400 orang. Teknik pengumpulan data yang digunakan dalam penelitian ini adalah dengan menggunakan angket kuesioner yang disebarkan ke melalui Google Form.

Jumlah sample $=\frac{19787}{1+(19787 \times 0.05)^{2}}=392$

Data yang dibutuhkan dalam menjawab tujuan artikel ini mencakup kesiapan pribadi dan lingkungan. Kesiapan pribadi mencakup (1) variabel psikis yang meliputi kepercayaan diri, konsentrasi, adaptasi, motivasi, dan (2) variabel fisik meliputi kesehatan, sedangkan kesiapan lingkungan mencakup (3) variabel lingkungan fisik yang mencakup sumber belajar, ketersediaan fasilitas belajar dan (4) variabel lingkungan sosial yang mencakup dukungan orang tua. Untuk melengkapi implikasi riset, data tentang hasil belajar selama belajar dari rumah dikumpulkan sebagai faktor pembanding mengukur kecenderungan kesiapan mereka dengan pemahaman mereka terhadap materi.

Instrumen yang digunakan melalui tahap uji validitas dan reliabilitas melalui SPSS. Uji validitas dengan menggunakan Product Pearson Correlation dan uji reliabilitas dengan uji Alpha Cornbach's SPSS. Hasil dari uji validitas dan reliabilitas menunjukkan bahwa seluruh instrumen layak dan bias digunakan sebagai alat pengumpul data. Data yang dikumpulkan dikelola melalui tahapan editing, coding, scoring, dan tabulating. Selanjutnya data dianalisis dengan menggunakan analisis statistik deskriptif berupa crosstab. Crosstab ini bertujuan untuk mengidentifikasi pola dan kecenderungan faktor kesiapan belajar siswa selama pembelajaran jarak jauh.

\section{HASIL DAN PEMBAHASAN}

Hasil

Tingkat kesiapan belajar jarak jauh siswa SMP di Kota Malang merupakan gambaran akumulasi dari faktor pribadi dan lingkungan. Akumulasi dari kedua faktor tersebut kemudian dibandingkan dengan kategori yang sudah ditentukan sebelumnya. Guna menggali lebih dalam tingkat kesiapan belajar jarak jauh siswa SMP di Kota Malang, data tabulasi tunggal dianalisis menggunakan tabulasi silang dengan tujuan untuk menggali pola kecenderungan antar faktor kesiapan belajar. Analisis tabulasi silang juga akan mampu menggambarkan bagaimana kecenderungan tingkat kesiapan belajar mereka dengan pemahaman materi (Tabel 2). 
Tabel 2. Tabulasi Silang Faktor Pribadi Tingkat Kesiapan Belajar terhadap Pemahaman Materinya Siswa SMP di Kecamatan Blimbing Kota Malang

\begin{tabular}{llrrrr}
\hline & & \multicolumn{2}{c}{ Pemahaman Materi } \\
& & Rendah & Sedang & Tinggi & Total \\
\hline Kesiapan & Rendah & 0 & 1 & 0 & 1 \\
Pribadi & Sedang & 0 & 5 & 4 & 9 \\
& Tinggi & 0 & 2 & 29 & 31 \\
\hline Total & & 0 & 8 & 33 & 41 \\
\hline
\end{tabular}

Sumber: Hasil analisis data menggunakan SPSS

Berdasarkan Tabel 2, menunjukkan bahwa siswa yang memiliki tingkat kesiapan pribadi dari dilihat kondisi psikis dan fisik yang tinggi cenderung memiliki penguasaan materi yang tinggi pula selama mengikuti pembelajaran jarak jauh. Hal ini menunjukkan bahwa dari total 41 siswa SMP Negeri di Kecamatan Blimbing yang mengisikan kuesionersudah siap mengalami perubahan pembelajaran tatap muka ke pembelajaran jarak jauh dengan mempersiapkan kondisi pribadinya.

Tabel 3. Tabulasi Silang Faktor Lingkungan Tingkat Kesiapan Belajar terhadap Pemahaman Materinya Siswa SMP di Kecamatan Blimbing Kota Malang

\begin{tabular}{llrrrr}
\hline & & \multicolumn{2}{c}{ Pemahaman Materi } & \\
& & Rendah & Sedang & Tinggi & Total \\
\hline Kesiapan & Rendah & 0 & 1 & 0 & 1 \\
Lingkungan & Sedang & 0 & 2 & 2 & 4 \\
& Tinggi & 0 & 5 & 31 & 36 \\
\hline Total & & 0 & 8 & 33 & 41 \\
\hline
\end{tabular}

Sumber: Hasil Analisis Data Menggunakan SPSS

Berdasarkan Tabel 3 menunjukkan bahwa siswa yang memiliki tingkat kesiapan lingkungan dari kondisi lingkungan fisik dan lingkungan sosialnya yang tinggi cenderung memiliki penguasaan materi yang tinggi pula selama mengikuti pembelajaran jarak jauh. Hal ini menunjukkan bahwa dari total 41 siswa SMP Negeri di Kecamatan Blimbing yang mengisikan kuesionersudah siap mengalami perubahan kegiatan pembelajaran tatap muka ke pembelajaran jarak jauh dengan mempersiapkan kondisi lingkungan fisik dan sosialnya.

Tabel 4. Tabulasi Silang Faktor Pribadi Kesiapan Belajar terhadap Pemahaman Materinya Siswa SMP Negeri di Kecamatan Kedungkandang Kota Malang

\begin{tabular}{llrrrr}
\hline & & \multicolumn{2}{c}{ Pemahaman Materi } & \\
& & Rendah & Sedang & Tinggi & Total \\
\hline Kesiapan & Rendah & 1 & 0 & 0 & 4 \\
Pribadi & Sedang & 4 & 37 & 53 & 94 \\
& Tinggi & 0 & 24 & 17 & 41 \\
\hline Total & & 5 & 61 & 70 & 136 \\
\hline
\end{tabular}

Sumber: Hasil Analisis Data Menggunakan SPSS

Berdasarkan Tabel 4 menunjukkan bahwa siswa yang memiliki tingkat kesiapan pribadi dari kondisi psikis dan fisik yang tinggi cenderung memiliki penguasaan materi yang tinggi pula selama mengikuti pembelajaran jarak jauh. Hal ini menunjukkan bahwa 136 siswa SMP Negeri di Kecamatan Kedungkandang yang mengisikan kuesionersudah siap mengalami perubahan kegiatan pembelajaran tatap muka ke pembelajaran jarak jauh dengan mempersiapkan kondisi pribadinya 
Tabel 5. Tabulasi Silang Faktor Lingkungan Kesiapan Belajar terhadap Pemahaman Materinya Siswa SMP Negeri di Kecamatan Kedungkandang Kota Malang

\begin{tabular}{llccrr}
\hline & & \multicolumn{3}{c}{ Pemahaman Materi } & \\
& & Rendah & Sedang & Tinggi & Total \\
\hline Kesiapan & Rendah & 2 & 0 & 0 & 2 \\
Lingkungan & Sedang & 3 & 23 & 2 & 28 \\
& Tinggi & 0 & 38 & 68 & 106 \\
\hline Total & & 76 & 13 & 47 & 136 \\
\hline
\end{tabular}

Sumber: Hasil Analisis Data Menggunakan SPSS

Berdasarkan Tabel 5 menunjukkan bahwa siswa yang memiliki tingkat kesiapan lingkungan dari kondisi lingkungan fisik dan lingkungan sosialnya yang tinggi cenderung memiliki penguasaan materi yang tinggi pula selama mengikuti pembelajaran jarak jauh. Hal ini menunjukkan bahwa dari 136 siswa SMP Negeri di Kecamatan Kedungkandang yang mengisi kuesioner sudah siap mengalami perubahan kegiatan pembelajaran tatap muka ke pembelajaran jarak jauh.

Tabel 6. Tabulasi Silang Faktor Pribadi Kesiapan Belajar Siswa Negeri SMP di Kecamatan Klojen Kota Malang

\begin{tabular}{lllrrrr}
\hline & & \multicolumn{2}{c}{ Pemahaman Materi } & \multicolumn{2}{c}{ Total } \\
\hline Kesiapan & Rendah & & Sedang & Tinggi & 1 \\
Pribadi & Sedang & 1 & 0 & 0 & 91 \\
& Tinggi & 4 & 34 & 53 & 44 \\
\hline Total & & 2 & 21 & 21 & 136 \\
\hline
\end{tabular}

Sumber: Hasil Analisis Data Menggunakan SPSS

Berdasarkan Tabel 6. menunjukkan bahwa siswa yang memiliki tingkat kesiapan pribadi dari psikis dan fisik yang tinggi cenderung memiliki penguasaan materi yang tinggi pula selama mengikuti pembelajaran jarak jauh. Hal ini menunjukkan bahwa dari 136 siswa SMP Negeri di Kecamatan Klojen yang mengisi kuesionersudah siap mengalami perubahan kegiatan pembelajaran tatap muka ke pembelajaran jarak jauh dengan mempersiapkan kondisi pribadinya.

Tabel 7. Tabulasi Silang Faktor Lingkungan Kesiapan Belajar Siswa SMP Negeri di Kecamatan Klojen Kota Malang

\begin{tabular}{lllcrr} 
& & \multicolumn{3}{c}{ Pemahaman Materi } & Total \\
\cline { 3 - 6 } & & Rendah & Sedang & Tinggi & 2 \\
Kesiapan & Rendah & 2 & 0 & 0 & 34 \\
Lingkungan & Sedang & 5 & 23 & 6 & 100 \\
& Tinggi & 0 & 32 & 68 & 136 \\
\hline Total & & 2 & 7 & 55 & \\
\hline
\end{tabular}

Sumber: Hasil Analisis Data Menggunakan SPSS

Berdasarkan Tabel 7 menunjukkan bahwa siswa yang memiliki tingkat kesiapan lingkungan dari lingkungan fisik dan lingkungan sosialnya yang tinggi cenderung memiliki penguasaan materi yang tinggi pula selama mengikuti pembelajaran jarak jauh. Hal ini menunjukkan bahwa siswa dari 136 SMP Negeri di Kecamatan Klojen yang mengisi kuesionersudah siap mengalami perubahan kegiatan pembelajaran tatap muka ke pembelajaran jarak jauh dengan mempersiapkan kondisi lingkungan fisik dan sosialnya. 
Tabel 8. Tabulasi Silang Faktor Pribadi Kesiapan Belajar Siswa SMP Negeri di Kecamatan Lowokwaru Kota Malang

\begin{tabular}{lcrrrr}
\hline & & \multicolumn{2}{c}{ Pemahaman Materi } & & \\
& & Rendah & Sedang & Tinggi & Total \\
\hline Kesiapan Pribadi & Rendah & 1 & 0 & 0 & 1 \\
& Sedang & 1 & 14 & 14 & 29 \\
& Tinggi & 0 & 9 & 97 & 106 \\
\hline Total & & 2 & 23 & 111 & 136 \\
\hline
\end{tabular}

Sumber: Hasil Analisis Data Menggunakan SPSS

Berdasarkan Tabel 8 menunjukkan bahwa siswa yang memiliki tingkat kesiapan pribadi dari psikis dan fisik yang tinggi cenderung memiliki penguasaan materi yang tinggi pula selama mengikuti pembelajaran jarak jauh. Hal ini menunjukkan bahwa dari 136 siswa SMP Negeri di Kecamatan Lowokwaru yang mengisi kuesionersudah siap mengalami perubahan kegiatan pembelajaran tatap muka ke pembelajaran jarak jauh dengan mempersiapkan kondisi pribadinya.

Tabel 9. Tabulasi Silang Faktor Lingkungan Kesiapan Belajar Siswa SMP Negeri di Kecamatan Lowokwaru Kota Malang

\begin{tabular}{lrrrrr}
\hline & & \multicolumn{2}{c}{ Pemahaman Materi } & Tinggi & Total \\
\hline Kesiapan & Rendah & Sedang & 0 & 1 \\
Lingkungan & 0 & 1 & 8 & 19 \\
& Sedang & 1 & 10 & 103 & 116 \\
\hline Total & Tinggi & 1 & 12 & 111 & 136 \\
\hline
\end{tabular}

Sumber: Hasil Analisis Data Menggunakan SPSS

Berdasarkan Tabel 9 menunjukkan bahwa siswa yang memiliki tingkat kesiapan lingkungan dari lingkungan fisik dan lingkungan sosialnya yang tinggi cenderung memiliki penguasaan materi yang tinggi pula selama mengikuti pembelajaran jarak jauh. Hal ini menunjukkan bahwa dari 136 siswa SMP Negeri di Kecamatan Lowokwaru yang mengisi kuesionersudah siap mengalami perubahan kegiatan pembelajaran tatap muka ke pembelajaran jarak jauh dengan mempersiapkan kondisi lingkungan fisik dan sosialnya

Tabel 10. Tabulasi Silang Faktor Pribadi Kesiapan Belajar Siswa SMP Negeri di Kecamatan Sukun Kota Malang

\begin{tabular}{rlrrrr}
\hline & & & Pemahaman Materi & \\
& & Rendah & Sedang & Tinggi & Total \\
\hline Kesiapan Pribadi & Rendah & 101 & 0 & 0 & 101 \\
& Sedang & 0 & 3 & 4 & 7 \\
& Tinggi & 0 & 7 & 21 & 28 \\
\hline Total & & 101 & 10 & 25 & 136 \\
\hline
\end{tabular}

Sumber: Hasil Analisis Data Menggunakan SPSS

Berdasarkan Tabel 10 menunjukkan bahwa siswa yang memiliki tingkat kesiapan pribadi dari psikis dan fisik yang tinggi cenderung memiliki penguasaan materi yang tinggi pula selama mengikuti pembelajaran jarak jauh. Hal ini menunjukkan bahwa dari 136 siswa SMP Negeri di Kecamatan Sukun yang mengisi kuesionersudah siap mengalami perubahan kegiatan pembelajaran tatap muka ke pembelajaran jarak jauh dengan mempersiapkan kondisi pribadinya 
Tabel 11. Tabulasi Silang Faktor Lingkungan Kesiapan Belajar Siswa SMP Negeri di Kecamatan Kedungkandang Kota Malang

\begin{tabular}{llrrrr}
\hline & & Pemahaman Materi & & \\
& & Rendah & Sedang & Tinggi & Total \\
\hline Kesiapan & Rendah & 101 & 0 & 0 & 101 \\
Lingkungan & Sedang & 0 & 5 & 4 & 9 \\
& Tinggi & 0 & 5 & 21 & 26 \\
\hline Total & & 101 & 10 & 25 & 136 \\
\hline
\end{tabular}

Sumber: Hasil Analisis Data Menggunakan SPSS

Berdasarkan Tabel 11 menunjukkan bahwa siswa yang memiliki tingkat kesiapan lingkungan dari lingkungan fisik dan lingkungan sosialnya yang tinggi cenderung memiliki penguasaan materi yang tinggi pula selama mengikuti pembelajaran jarak jauh. Hal ini menunjukkan bahwa dari 136 siswa SMP Negeri di Kecamatan Sukun yang mengisi kuesionersudah siap mengalami perubahan kegiatan pembelajaran tatap muka ke pembelajaran jarak jauh dengan mempersiapkan kondisi lingkungan fisik dan sosialnya.

Tabel 12. Tabel Kategorisasi Tingkat Pemahaman Materi Siswa

\begin{tabular}{ccl}
\hline Rentang kelas & Kategori \\
\hline $1-4$ & Rendah \\
$5-12$ & Sedang \\
$13-16$ & Tinggi \\
\hline
\end{tabular}

Sumber: Analisis Data Primer

Pemahaman peserta didik dievaluasi dari empat aspek utama, yaitu pemahaman materi yang disampaikan, kesesuaian kegiatan belajar, kesesuaian media yang digunakan dalam penyampaian materi, kesesuaian pemilihan perangkat lunak (aplikasi) yang digunakan dalam menyampaikan materi. Seluruh komponen pemahaman siswa menggambarkan bagaimana proses pembangunan pengetahuan dalam kegiatan pembelajaran jarak jauh. Kesiapan pemahaman materi, didapatkan dari 4 item pertanyaan dengan nilai maksimal adalah 16 dan nilai minimal adalah 4 , maka kategorisasi dalam faktor pemahaman materi dapat dilihat pada tabel (12).

Tabel 13. Pemahaman Materi Siswa SMP Negeri di Kota Malang

\begin{tabular}{lrrrrr}
\hline \multirow{2}{*}{ Pemahaman Materi } & \multicolumn{7}{c}{ Jumlah (\%) } \\
\cline { 2 - 6 } & Blimbing & Kedung Kandang & Klojen & Lowokwaru & Sukun \\
\hline Rendah & 0,00 & 3,33 & 5,47 & 4,41 & 0,00 \\
Sedang & 39,02 & 45,00 & 40,63 & 34,56 & 48,57 \\
Tinggi & 60,98 & 51,67 & 53,91 & 61,03 & 51,43 \\
\hline Jumlah & 100,00 & 100,00 & 100,00 & 100,00 & 100,00 \\
\hline
\end{tabular}

Sumber: Analisis Data Menggunakan SPSS

Berdasarkan Tabel 13 dapat disimpulkan bahwa siswa SMP Negeri di Kota ratarata memiliki kesiapan sedang hingga tinggi. Kondisi ini menunjukkan bahwa wilayah kota yang memiliki akses terhadap jaringan internet tidak menjamin pemahaman materi mereka, kondisi yang mempengaruhi adalah bagaimana kesiapan belajar siswa. Hal ini menunjukkan bahwa semakin tinggi kesiapan belajar siswa maka memiliki kecenderungan untuk pemahaman materi yang semakin tinggi pula. Kesiapan pemahaman materi tertinggi $(61,03 \%)$ ada di Kecamatan Lowokwaru. 


\section{Pembahasan}

Pemerintah Kota Malang telah memutuskan untuk memanfaatkan teknologi untuk proses pembelajaran selama pandemi dengan sistem pembelajaran jarak jauh agar siswa dapat tetap dapat berinteraksi dengan guru. Hal ini didukung oleh pendapat Menard \& Ratnapalan (2013) bahwa perkembangan teknologi informasi dan komunikasi, menjadikan interaksi antara pengajar dan pembelajar dapat dilakukan baik dalam bentuk sinkronus atau asinkronus. Tingkat kesiapan siswa dalam mengikuti pembelajaran jarak jauh dapat dilihat dari siswa-siswi SMP di Kota Malang mayoritas tidak merasa kesulitan dalam mengakses materi pembelajaran lewat platform belajar Google Classroom, Google Meet, Zoom, dan materi yang disampaikan guru melalui WhatsApp Group. Pengelolaan sistem pembelajaran tatap muka dengan sistem pembelajaran jarak jauh berbeda dalam aspek interaksi guru dan siswa. Bentuk interaksi yang kita kelola bisa melalui model sinkronus atau real time melalui video conference, atau model asinkronus melalui forum diskusi dan bahkan beberapa menggunakan media sosial (Garrison \& Archer, 2010).

Hasil temuan di lapangan menunjukkan bahwa siswa SMP Negeri di Kota Malang menggunakan platform Google Meet, Google Classroom, Zoom dalam proses interaksi bersama guru dan semua kegiatan pembelajaran berlangsung seperti diskusi, penyampaian materi, tes, dan penilaian dilakukan dalam platform tersebut. Desain dari interaksinya sebaiknya sudah direncanakan dengan baik untuk mencapai tujuan pembelajaran. Hal ini sama dengan pendapat Garrison \& Archer (2010) tentang pengelolaan sistem pembelajaran jauh yang efektif harus memperhatikan skenario pembelajaran yang bisa memandu siswa belajar yaitu RPP yang terus direvisi agar tidak menyulitkan siswa belajar, mempersiapkan konten materi yang bisa memandu siswa belajar melalui video edukasi atau power point.

Kesiapan belajar siswa dari faktor pribadi dan lingkungan memiliki kecenderungan terhadap pemahaman materi siswa selama pembelajaran jauh. Kecenderungan kesiapan belajar siswa SMP di Kota Malang terhadap pemahaman materi cenderung tinggi. Hal ini menunjukkan bahwa siswa yang mempersiapkan diri baik secara psikis maupun lingkungan cenderung lebih baik dalam memahami materi selama mengikuti pembelajaran. Pemahaman materi siswa dipengaruhi oleh kesiapan konsentrasi siswa dalam mengikuti kegiatan pembelajaran jarak jauh di rumah. Selama mengikuti pembelajaran jarak jauh di rumah kondisi lingkungan siswa mempengaruhi konsentrasi siswa dalam belajar (Fisher \& Imms, 2016). Tingkat kesiapan siswa akan membawa individu untuk siap memberikan tanggapan/respon terhadap situasi yang dihadapi melalui caranya sendiri. Selama mengikuti pembelajaran jarak jauh tingkat kesiapan belajar siswa dilihat apakah siswa dapat menerima stimulus dari guru melalui pembelajaran daring, tentunya hal ini berbeda dengan stimulus yang diberikan guru saat pembelajaran tatap muka di kelas. Respon yang diberikan siswa terhadap pembelajaran yang diterimanya sangat menentukan keberhasilan siswa dalam belajar. Teori classical conditioning Pavlov (1932) yang menyatakan bahwa siswa yang dapat memberikan respon terhadap materi belajar yang diterima selama mengikuti pembelajaran akan mempengaruhi tingkah laku yang dihasilkan dari merespon pembelajaran termasuk dalam kesiapan siswa dalam merespon pembelajaran. Kondisi kesiapan siswa dibutuhkan dalam pembelajaran guna mencapai tujuan pembelajaran serta keberhasilan siswa dalam belajar. 
Analisis kesiapan siswa dalam mengikuti pembelajaran jarak jauh wajib dilakukan pada tahap awal pembelajaran. Tahap ini disebut dengan asesmen diagnostik dengan tujuan utama untuk mengevaluasi kapabilitas dan kebutuhan belajar siswa. Tahap ini menjadi penting untuk dilakukan guna menentukan desain pembelajaran yang sesuai dengan karakter dan kebutuhan siswa (Suwarto, 2013). Implementasi dan literasi digital siswa juga merupakan aspek pendukung pelaksanaan pembelajaran jarak jauh (Belawati, 2020).

Kesiapan belajar siswa dari faktor pribadi dan lingkungan memiliki kecenderungan terhadap pemahaman materi siswa selama pembelajaran jauh. Kecenderungan kesiapan belajar siswa SMP Negeri di Kota Malang terhadap pemahaman materi cenderung tinggi. Hal ini menunjukkan bahwa siswa yang mempersiapkan diri baik secara psikis maupun lingkungan cenderung lebih baik dalam memahami materi selama mengikuti pembelajaran. Pemahaman materi siswa dipengaruhi oleh kesiapan konsentrasi siswa dalam mengikuti kegiatan pembelajaran jarak jauh di rumah. Selama mengikuti pembelajaran jarak jauh di rumah kondisi lingkungan siswa mempengaruhi konsentrasi siswa dalam belajar (Fisher \& Imms, 2016). Kesiapan psikis siswa terutama dalam hal konsentrasi belajar sangat mempengaruhi pemahaman materi dalam proses belajar siswa selama mengikuti pembelajaran jarak jauh di rumah. Hal ini didukung oleh penelitian dari Aviana dan Hidayah yang menunjukkan bahwa penyebab utama rendahnya prestasi siswa adalah kemampuan konsentrasi siswa yang lemah (Hidayah \& Aviana, 2015). Kesiapan belajar siswa SMP Negeri di Kota Malang menunjukkan bahwa kecenderungan tingkat kesiapan belajar siswa terhadap pemahaman materi siswa dalam tingkat sedang. Kecenderungan pemahaman materi siswa dapat dipengaruhi oleh beberapa faktor seperti respon siswa terhadap materi yang lambat, kondisi lingkungan yang tidak mendukung, sumber belajar yang kurang dan ketersediaan fasilitas belajar yang terbatas. Apabila siswa dapat menggunakan kata-katanya sendiri untuk memberikan penjelasan atau memberikan gambaran yang lebih detail maka dapat dikatakan bahwa siswa tersebut memahami sesuatu (Anas, 2012). Selama siswa memiliki tingkat kesiapan belajar yang tinggi maka semakin tinggi pula kecenderungan siswa terhadap tingkat pemahaman materi selama pembelajaran jarak jauh.

\section{KESIMPULAN}

Hasil analisis tabulasi silang menunjukkan kesiapan belajar siswa SMP Negeri di Kota Malang dilihat dari variabel faktor pribadi dan faktor lingkungan menjadi faktor pendukung tingkat kesiapan belajar siswa SMP Negeri di Kota Malang cenderung tinggi. Semakin tinggi tingkat kesiapan belajar siswa selama mengikuti pembelajaran jarak jauh maka siswa akan semakin siap dalam menerima dan merespon materi pembelajaran meskipun kegiatan pembelajaran dilakukan di rumah. Hasil analisis tabulasi silang menunjukkan bahwa semakin tinggi tingkat kesiapan belajar siswa dari faktor pribadi dan lingkungan maka semakin tinggi kecenderungan pemahaman materi siswa selama mengikuti pembelajaran jarak jauh. Kontribusi hasil penelitian ini memberikan gambaran bagaimana kesiapan siswa dalam mengikuti pembelajaran jarak jauh, namun tidak mengevaluasi komponen pembelajaran secara menyeluruh. Oleh karena itu direkomendasikan untuk menindaklanjuti dengan mengevaluasi pengelolaan pembelajaran jarak jauh dilakukan berdasarkan profil kesiapan yang ada mengingat krisis Covid-19 masih menjadi ancaman nasional. 


\section{DAFTAR PUSTAKA}

Anas. (2012). Pengantar Evaluasi Pendidikan. Jakarta: PT. Raja Grafindo Persada.

Belawati, T. (2020). Pembelajaran Daring yang Efektif. Jakarta.

Fisher, \& Imms, C. (2016). valuating Learning Environment: snapshots or emerging issues, methods and knowledge.

Garrison, A. R., \& Archer, W. (2010). The First Decade of The Community of Inquiry Framework: A retrospective. Internet and Higher Education. pp. 5-9., 13(1),

Hidayah, F., \& Aviana, R. (2015). engaruh Tingkat Konsentrasi Belajar Siswa Terhadap Daya Pemahaman Materi Pada Pembelajaran Kimia di SMA Negeri 2 Batang. Jurnal Pendidikan Sains, III(3), p. 3.

Kemendikbud. (2020). Kemendikbud Imbau Pendidik Hadirka Belajar Menyenangkan Bagi Daerah yang Terapkan Belajar di Rumah. Jakarta: Kementrian Pendidikan dan Kebudayaan.

Kemendikbud. (2020). Pencegahan Covid-19 pada Satuan Pendidikan. Jakarta: Kementrian Pendidikan dan Kebudayaan.

Kristanto, Y. D. (2020). COVID-19, Merdeka Belajar, dan Pembelajaran Jarak Jauh. Lisensi Creative Commons Atribusi 4.0 Internasional.

Purnomo, A. (2020). Survey belajar jarak jauh bagi pelajar di Indonesia. Kota Malang: Universitas Negeri Malang.

Ristekdikti. (2016). Kebijakan Pendidikan Jarak Jauh dan E-Learning di Indonesia. Jakarta: Kementrian Riset Teknologi dan Pendidikan Tinggi.

Sabuga, I. (2020, 4 30). Wawancara pembelajaran jarak jauh di Kabupaten Flores Timur Nusa Tenggara TImur.

Santosa, A. (2020). Potret Pendidikan di Tahun Pandemi: Dampak COVID-19 Terhadap Disparitas Pendidikan di Indonesia. Research Intern, Departmen Hubungan Internasional CSIS Indonesia.

Setiaji, B., \& Dinata, P. A. (2020). Analisis Kesiapan Mahasiswa Jurusan Pendidikan Fisika Menggunakan E-Learning dalam Situasi Pandemi Covid-19. Jurnal Inovasi Pendidikan IPA, doi:https://doi.org/10.21831/jipi.v6i1.31562, 6(1), 59-70.

Slameto. (2013). Belajar dan Faktor-Faktor yang Mempengaruhinya. Jakarta: Rineka Cipta. 
Sutiaji. (2020). Surat Edaran Walikota Malang tentang pembelajaran jarak jauh. Kota Malang: Pemerintah Kota Malang.

Suwarto. (2013). Pengembangan Tes Diagnostik dalam Pembelajaran. Yogyakarta: Pustaka Pelajar.

Tilak, S., \& Glassman, M. (2020). Alternative lifeworlds on the Internet: Habermas and democratic distance education. Distance Education, 41(3), 326-344. 